Article

\title{
Using Chemically Enhanced Primary Treatment (CEPT) as a Pretreatment Option for Anaerobic Digestate from Cattle Manure Digestion System
}

\author{
Weijia Gong ${ }^{1, *} \mathbb{D}$, Lina Luo ${ }^{1}$, Wenzhe $\mathrm{Li}^{1}$, Xinsheng Luo ${ }^{2}$, Heng Liang ${ }^{2} \mathbb{D}^{\mathbb{D}}$, Huu Hao $\mathrm{Ngo}^{3}$ and \\ Wenshan Guo ${ }^{3}$ (D) \\ 1 School of Engineering, Northeast Agriculture University, 59 Mucai Street, Xiangfang District, \\ Harbin 150030, China; luolina21333@163.com (L.L.); liwenzhe9@163.com (W.L.) \\ 2 State Key Laboratory of Urban Water Resource and Environment, Harbin Institute of Technology, \\ 73 HuangheRoad, Nangang District, Harbin 150090, China; luoxinsheng2008@163.com (X.L.); \\ hitliangheng@163.com (H.L.) \\ 3 Faculty of Engineering, University of Technology, P.O. Box 123, Broadway, Sydney NSW 2007, Australia; \\ HuuHao.Ngo@uts.edu.au (H.H.N.); Wenshan.Guo-1@uts.edu.au (W.G.) \\ * Correspondence: neaugong@163.com; Tel.: +86-451-5519-1760
}

Received: 28 May 2017; Accepted: 28 June 2017; Published: 3 July 2017

\begin{abstract}
Anaerobic digestate from cattle manure fermentation may pose a threat to the environment. How to stabilize the digestate's characteristics so that they do not disturb the bio-system is a critical issue for digestate management. Chemically enhanced primary treatment (CEPT) was investigated as a pretreatment option for digestate treatment. The performance of CEPT for digestate management was carried out under rapid mixing $(200 \mathrm{r} / \mathrm{min})$ and slow stirring $(40 \mathrm{r} / \mathrm{min})$, respectively. The optimal dosage of ferric chloride $\left(\mathrm{FeCl}_{3}\right)$ was $40 \mathrm{mg} / \mathrm{L}$. The combination of $\mathrm{FeCl}_{3}$ and anionic polyacrylamide (APAM) had no obvious influence on TP removal, while COD removal efficiency was improved by $15.4 \%$. The digestate $\mathrm{pH}$ and temperature remained stable for CEPT application and required no adjustment. The results indicate that CEPT was effective and feasible in enhancing the removal of COD and TP for digestate pretreatment by using $\mathrm{FeCl}_{3}$ and $\mathrm{APAM}$.
\end{abstract}

Keywords: anaerobic digestion (AD); digestate; chemically enhanced primary treatment (CEPT); pretreatment; ferric chloride

\section{Introduction}

In recent years, the handling and recycling of animal manure and organic wastes has received considerable attention [1]. Using animal manure and organic wastes as feedstock means that renewable energy systems create environmental, energy, and economic benefits simultaneously such as greenhouse gas (GHG) reduction, clean energy supply, and cost savings [2]. Wastes can be converted into different and useful forms of energy through various technologies and processes. One promising process for biological conversion of organic wastes is anaerobic digestion (AD), which turned wastes into renewable energy and biofuel in the form of methane. This method is arousing more interest because it has the ability to mitigate the impact of wastes on the environment and facilitate sustainable development $[3,4]$. AD is an effective biochemical process for organic waste treatment and for biogas production because AD offers numerous significant advantages, such as low sludge production, low energy requirement, and green energy recovery. It has been evaluated as one of the most energy-efficient and environmentally beneficial technologies for bioenergy production [5-7].

$\mathrm{AD}$ or co-digestion of organic wastes has been extensively researched and demonstrated. Although the AD process for organic waste treatment is very complicated and requires further 
analysis before it is employed in commercial applications, it has become the default process for biological conversion of organic wastes into renewable energy in the form of methane. The application of $\mathrm{AD}$ for the treatment of organic wastes has made spectacular advances in recent years $[3,8,9]$. On the other hand, an organic matter-rich solid waste is generated after the AD process, which is defined as digestate [10]. The properties of digestate are highly dependent on the properties of the feedstock used [11]. Applying digestate as fertilizer was once considered to be the most suitable way to enrich nutrients, and its quality must satisfy the needs of nations' regulatory frameworks [12]. Due to the increasingly strict regulations on its contents of heavy metals, pathogens, and organic pollutants, concerns regarding anaerobic digestate's appropriate disposal, treatment, and reuse have increased [12,13]. In addition, the feasibility of its direct fertilization of soil will be constrained by transport requirements.

Having many large-scale biogas plants operating may lead to an oversupply of digestate in certain regions. If the use of digestate is limited by agricultural area, the surplus has to be transported elsewhere, meaning that transportation costs and logistical problems have to be considered [14]. If the digestate has to be discharged into the environment, the post-treatments essential for $\mathrm{AD}$ alone may lead to effluent failing to meet discharge standard requirements as used in most industrialized countries. Based on an assessment of the current status of digestate treatment technologies, the applied treatment concepts can be classified into two approaches: partial treatment or complete purification [15]. Generally, partial treatment aims mainly to reduce quantity or serve as a pretreatment unit for subsequent processes. The complete purification process mainly concentrates on valuable nutrients and advanced purification for safe discharge.

Membrane technologies have proven effective for the advanced treatment of digestate [15-17]. Membrane technologies can assist in the concentration of purification in two ways. Concentration usually plays an important role in making digestate transportation economically feasible and beneficial as a fertilizer $[18,19]$. For areas where digestate is not available for agricultural purposes during cold seasons, purification can help to protect the environment by removing pollutants effectively [15,20-22]. It has been reported that anoxic/oxic-membrane bioreactor (A/O-MBR) was technically feasible for the treatment of digestate, and can provide an environmentally acceptable way for the application of wet-AD in animal manure treatment [16]. However, it was found that wide variations of digestate quality could affect A/O-MBR efficiencies adversely during the year. The contents of digestate are often varied: firstly, according to the composition of feedstock digested; and secondly, over time for the same AD plant [15]. How to provide a stable and good quality digestate for the A/O-MBR system has become a critical issue in full-scale biogas plants. If high-quality AD feedstock cannot be guaranteed all the time, effective pretreatment for the subsequent system may be a better solution to stabilize the quality of influent for biological treatment processes.

Chemically enhanced primary treatment (CEPT) is a process that has been known for more than 100 years. However, its application to wastewater was consolidated only in the past two decades based on technological development of coagulation [23]. CEPT can remove suspended solids (SS), colloids, and total phosphorus (TP) effectively. According to the literatures, CEPT can remove SS (90\%), BOD (50-70\%), COD (50-60\%), and TP (80-90\%) [23-27]. Furthermore, CEPT possesses many other advantages, such as reducing the footprint of pretreatment unit, reducing the cost, low energy requirement, easy to operation and maintenance, etc. [26]. However, CEPT is not very effective in removing ammonium and dissolved organics, which limits the application of CEPT [25,27]. Little work has been reported on the application of coagulants with cationic polymers for CEPT of digestate. The objective of this study was to evaluate the effectiveness of CEPT as a pretreatment option for anaerobic digestate from a cattle manure digestion system. Based on the efficiency in removing COD and TP, the CEPT process was optimized to achieve the most suitable parameters for ensuring the effluent was of a quality suitable for A/O-MBR. 


\section{Materials and Methods}

\subsection{Experimental}

The literature has documented that residual alum is harmful to human health and iron coagulants are more suitable for application in CEPT [28,29]. According to the influent's qualities and former results on wastewater treatment, ferric chloride $\left(\mathrm{FeCl}_{3}\right)$ was selected for its popularity and easy-to use features, and anionic polyacrylamide (APAM) was used as a coagulant aid.

\subsection{Wastewater Characteristics}

The digestate was extracted from the supernatant after $24.0 \mathrm{~h}$ sedimentation of effluent being discharged from AD treatment of cow manure. The main parameters of the digestate used in this study are shown in Table 1.

Table 1. Characteristics of the digestate used.

\begin{tabular}{cccc}
\hline Parameter & Average Value & Minimum Value & Maximum Value \\
\hline $\mathrm{pH}$ & 7.31 & 7.03 & 7.78 \\
$\mathrm{COD}(\mathrm{mg} / \mathrm{L})$ & 4352 & 2687 & 5088 \\
$\mathrm{TP}(\mathrm{mg} / \mathrm{L})$ & 132 & 107 & 158 \\
\hline
\end{tabular}

\subsection{Sampling and Analytical Methods}

Measurements of the conventional parameters such as $\mathrm{pH}, \mathrm{COD}$, and $\mathrm{TP}$ were conducted according to the standard methods [30]. The chemical oxygen demand (COD) concentration was measured though the rapid digested spectrophotometry method using potassium dichromate with a microware digestion system (XJ-III, Taihong medical instrument Co., Ltd., Shaoguan, China). The concentrations of TP were determined using a UV-Vis spectrometer (UV-8000S, Shanghai Metash instrument Co., Ltd., Shanghai, China) at wavelengths of $700 \mathrm{~nm}$. The pH was measured using a pH meter (PB-21, Sartorius, Goetingen, Germany), which was calibrated weekly using commercial buffer solutions.

\subsection{Experimental Procedure}

In our experiment, 1 L beaker was used as container. MY3000-6M (Wuhan Meiyuyiqi Co., Ltd., Wuhan, China) six-link coagulation test agitator apparatus was also employed in CEPT tests. In order to ensure the analysis of the quantity of water samples, $6 \mathrm{~L}$ biogas was used in each test group, and the supernatant of $400 \mathrm{~mL} \times 6$ was used for measurement after the static precipitation. Jar tests were conducted with rapid mixing for $1 \mathrm{~min}$, slow stirring for $10 \mathrm{~min}$, and sedimentation for $15 \mathrm{~min}$. $\mathrm{FeCl}_{3}$ was dosed when rapid mixing began and $5 \mathrm{~min}$ later PAM was dosed (during combined use). From past experience, several different stirring speeds were compared to achieve different coagulation strengths. Different conditions used in the experiments are shown in Table 2. After sedimentation, the supernatants were sucked using a pipette to measure COD and TP values. The chemical oxygen demand (COD) total phosphorus (TP) removal efficiency was calculated by Equations (1) and (2)

$$
\begin{gathered}
\mathrm{COD}_{\text {removed }}(\%)=\frac{\mathrm{COD}_{\text {influent }}-\mathrm{COD}_{\text {effluent }}}{\mathrm{COD}_{\text {influent }}} \times 100 \\
\mathrm{TP}_{\text {removed }}(\%)=\frac{\mathrm{TP}_{\text {influent }}-\mathrm{TP}_{\text {effluent }}}{\mathrm{TP}_{\text {influent }}} \times 100
\end{gathered}
$$

where $\mathrm{COD}_{\text {influent }}$ and $\mathrm{TP}_{\text {influent }}$ were the $\mathrm{COD}$ and $\mathrm{TP}$ in the extracted digestate, respectively. $\mathrm{COD}_{\text {effluent }}$ and $\mathrm{TP}_{\text {effluent }}$ is the COD and TP concentration in the effluent after CEPT, respectively. 
Table 2. Experimental conditions.

\begin{tabular}{ccccccc}
\hline Condition & C1 & C2 & C3 & C4 & C5 & C6 \\
\hline Rapid mixing $(\mathrm{r} / \mathrm{min})$ & 300 & 200 & 300 & 200 & 300 & 200 \\
Slow stirring $(\mathrm{r} / \mathrm{min})$ & 30 & 30 & 40 & 40 & 50 & 50 \\
\hline
\end{tabular}

\section{Results}

\subsection{Effect of Conditions and Dosages on CEPT's Efficiencies}

\subsubsection{COD Removal}

The dosing of $\mathrm{FeCl}_{3}$ could help to remove $\mathrm{COD}$, and the removal efficiencies increased with incremental dosages under different conditions. It is shown in Figure 1 that removing COD by CEPT could be much more efficient at the dosages of 20,40, and $60 \mathrm{mg} / \mathrm{L}$, respectively. It could be seen that an optimum range existed for coagulant dosing in COD removal. The best COD removal efficiency was achieved using $40 \mathrm{mg} / \mathrm{L}$ coagulant, and no obvious enhanced removal efficiencies resulted by increasing the dosage. From Figure 1, it is also evident that the best coagulation scenario was $\mathrm{C} 4$ (rapid mixing at $200 \mathrm{r} / \mathrm{min}$, slow stirring at $40 \mathrm{r} / \mathrm{min}$ ) under different dosages. Furthermore, the most efficient removal of COD was $60 \%$ at $40 \mathrm{mg} / \mathrm{L}, \mathrm{C} 4$.

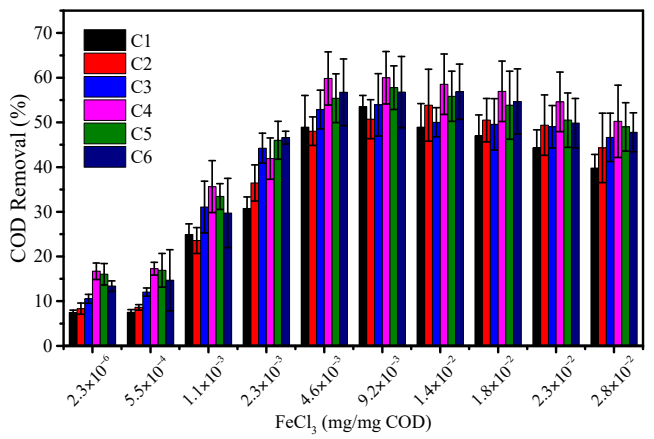

Figure 1. Effect of coagulation on COD removal efficiencies.

\subsubsection{TP Removal}

According to the literature, CEPT is efficient in removing TP. Figure 2 shows that $\mathrm{FeCl}_{3}$ can remove TP efficiently under different coagulation conditions. Removal efficiency increased with the dosing and achieved stability at a dosage of $40 \mathrm{mg} / \mathrm{L}$. Also, the C4 improved TP removal efficiency than under other conditions. Given the chemical cost and energy consumption, the best TP removal efficiency was $98.51 \%$ at $40 \mathrm{mg} / \mathrm{L}$ under C4.

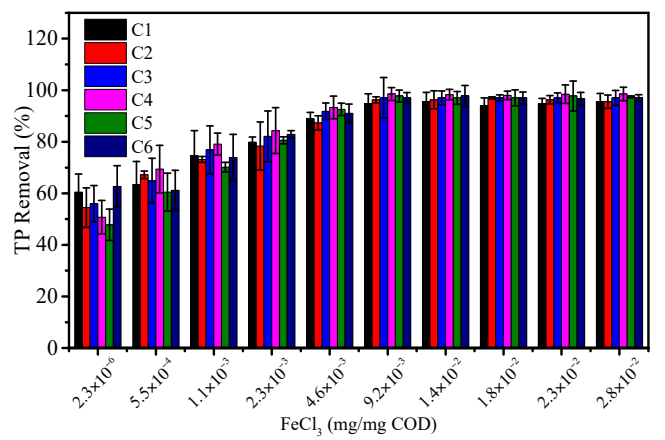

Figure 2. Effect of coagulation on TP removal efficiencies. 


\subsection{Efficiencies of Combined Use of $\mathrm{FeCl}_{3}$ and APAM in CEPT}

The combination of coagulants with anionic polymers as a coagulant aid for CEPT of wastewater also exhibited better removal efficiencies for pollutants [31,32]. The combined uses of anionic polyacrylamide (APAM) with coagulants in wastewater treatment have been reported as resulting in a number of benefits, for example: improving efficiency in removing pollutants while saving coagulants; and producing less sludge volumes with good dewaterability [31-33]. In Figure 3, it was shown that the addition of APAM can increase COD removal efficiencies for CEPT, while no obvious effects were noted for TP removal. The reason should be that $\mathrm{FeCl}_{3}$ itself can remove TP efficiently and the improving space is limited. With reference to COD removal, $0.1 \mathrm{mg} / \mathrm{L}$ APAM could increase COD removal efficiency by $10.2 \%$ and $0.2 \mathrm{mg} / \mathrm{L}$ APAM could increase it by $15.4 \%$. Table 3 shows that CEPT was effective as a pretreament in COD and TP removal. The combined use of $\mathrm{FeCl}_{3}$ and APAM had no obvious effect on TP removal, while COD removal efficiency significantly increased by $15 \%$ with $0.2 \mathrm{mg} / \mathrm{L}$ APAM addition. However, the COD and TP removal efficiency are still lower than some previous reports due to the special properties of digestate. The complicated chemical composition and high organic content of the digestate could severely affect the performance of CEPT.

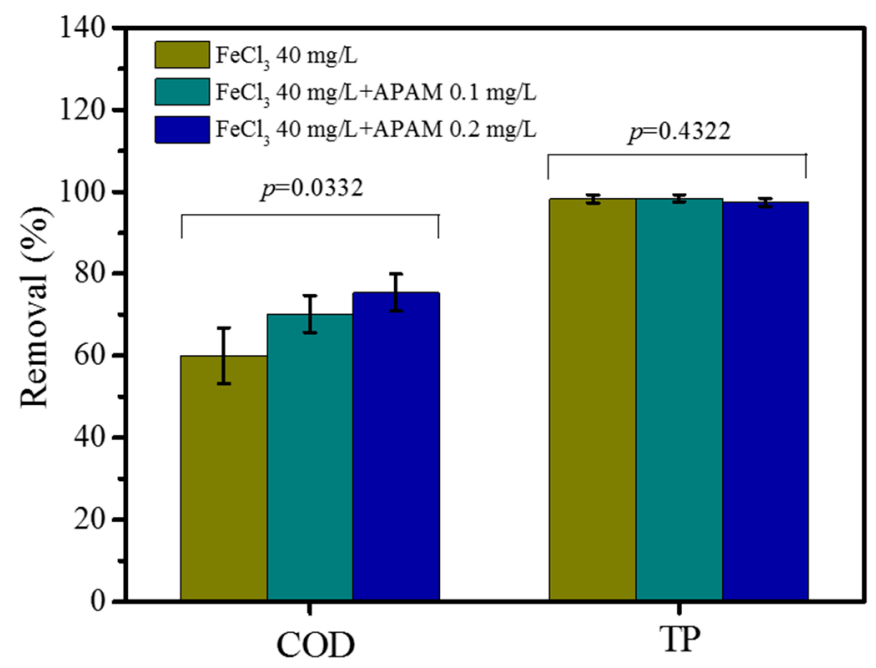

Figure 3. Effect of $\mathrm{FeCl}_{3}+\mathrm{APAM}$ dosing on anaerobic digestate treatment $\left(\mathrm{FeCl}_{3}=40 \mathrm{mg} / \mathrm{L}\right)$.

Table 3. The comparison of CEPT's efficiencies.

\begin{tabular}{cccc}
\hline CEPT & COD (\%) & TP (\%) & Reference \\
\hline $\mathrm{Fe}_{2}\left(\mathrm{SO}_{4}\right)_{3}$ & 78 & 99 & \\
$\mathrm{Fe}_{2}\left(\mathrm{SO}_{4}\right)_{3}$ and APAM & 94 & 99 & {$[31]$} \\
$\mathrm{Al}_{2}\left(\mathrm{SO}_{4}\right)_{3}$ & 87 & 99 & \\
$\mathrm{Al}_{2}\left(\mathrm{SO}_{4}\right)_{3}$ and APAM & 88 & 99 & \\
\hline $\mathrm{HP}-\mathrm{PACl}$ & 69 & 78 & {$[26]$} \\
\hline $\mathrm{FeCl}_{3}$ & 58 & 90 & {$[34]$} \\
\hline $\mathrm{FeCl}_{3}$ & 60 & 98 & This study \\
$\mathrm{FeCl}_{3}$ and APAM & 75 & 97 & \\
\hline
\end{tabular}

\subsection{Factors Influencing CEPT's Efficiencies}

The efficiency of CEPT may vary according to changes in temperature, $\mathrm{pH}$, and coagulation conditions [23]. Coagulation conditions have been investigated and compared. The effects of temperature and $\mathrm{pH}$ on CEPT's efficiencies are described in more detail below. 
Inorganic coagulant's hydrolysis is an endothermic reaction, and therefore low temperatures could affect hydrolysis reaction adversely and impair the CEPT's effectiveness. It was shown that temperature had obvious effects on COD and TP removal (see Figure 4.). The removal efficiency increased by $27.5 \%$ (COD) and $36.9 \%$ (TP) respectively, when the temperature rose from $5{ }^{\circ} \mathrm{C}$ to $25{ }^{\circ} \mathrm{C}$. For the treated digestate from cattle manure fermentation, the methanogenic tank's temperature was retained at $35 \pm 1{ }^{\circ} \mathrm{C}$, the digestate's temperature varied from $18{ }^{\circ} \mathrm{C}$ to $23{ }^{\circ} \mathrm{C}$. The digestate's temperature range had no apparent impact on CEPT's effectiveness based on the results under different temperatures. Consequently, no measures were needed to optimize temperature for improving CEPT.
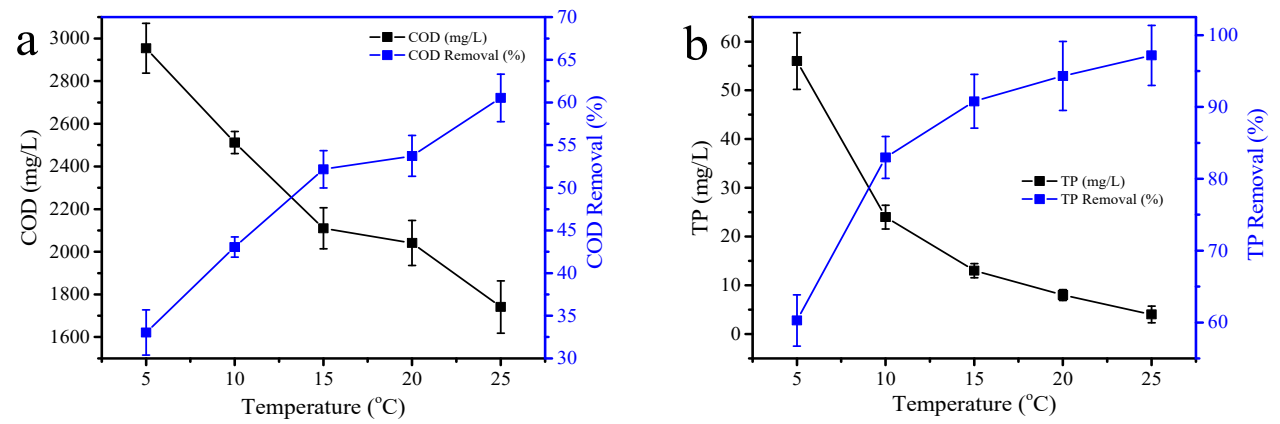

Figure 4. Effect of temperatures on CEPT efficiencies: (a) COD removal and (b) TP removal $\left(\mathrm{FeCl}_{3}\right.$ $40 \mathrm{mg} / \mathrm{L}$, APAM $0.2 \mathrm{mg} / \mathrm{L})$.

The coagulation process is sensitive to a solution's $\mathrm{pH}$ for the hydrolysis and bridge processes are directly related to solution $\mathrm{pH}$. From Figure 5, it is evident that CEPT remained stable in its operation at a $\mathrm{pH}$ of 6-9, and the best COD removal efficiency (increasing by $3.7 \%$ compared with the lowest) was achieved at $\mathrm{pH}$ 7.0. Meanwhile the best TP removal efficiency (increasing by $3.5 \%$ compared with the lowest) was achieved at $\mathrm{pH}$ 8.0. The digestate's $\mathrm{pH}$ varied from 7.03 to 7.78 during the whole experimental phase, and $\mathrm{Fe}(\mathrm{OH})_{3}$ was reported to be an atypical amphoteric compound that is suitable when the $\mathrm{pH}$ ranges from 5 to 10 [25]. Thus, there was no need to adjust $\mathrm{pH}$ for optimizing CEPT.
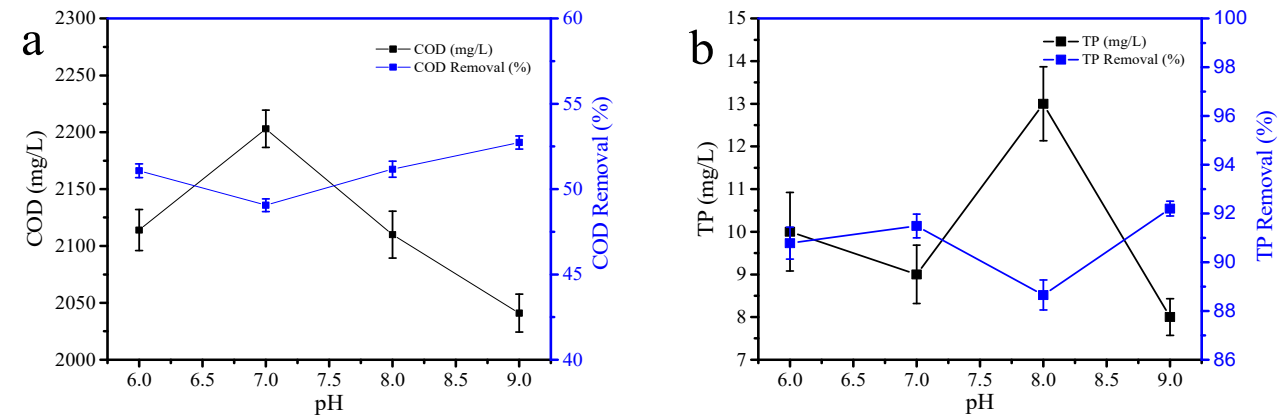

Figure 5. Effect of $\mathrm{pH}$ on CEPT efficiencies: (a) COD removal and (b) $\mathrm{TP}$ removal $\left(\mathrm{FeCl}_{3} 40 \mathrm{mg} / \mathrm{L}\right.$, APAM $0.2 \mathrm{mg} / \mathrm{L})$.

\section{Conclusions}

The treatment of anaerobic digestate derived from cattle manure fermentation by means of CEPT using $\mathrm{FeCl}_{3}$ and APAM was investigated in this study. The experimental results demonstrate that CEPT was effective as a pretreament in COD and TP removal, which can alleviate the subsequent A/O-MBR's load and improve the effluent's quality. The best coagulation scenario was rapid mixing $\left(200 \mathrm{r} / \mathrm{min}\right.$ ) and slow stirring $(40 \mathrm{r} / \mathrm{min})$ at the best dosage of $40 \mathrm{mg} / \mathrm{L} \mathrm{FeCl}_{3}$. The combined use of $\mathrm{FeCl}_{3}$ and APAM had no obvious effect on TP removal, while COD removal efficiency significantly 
increased by $15.4 \%$ with $0.2 \mathrm{mg} / \mathrm{L}$ APAM. Finally, the digestate's $\mathrm{pH}$ and temperature remained at a suitable status for CEPT's application and no adjustments were required.

Acknowledgments: This research was jointly supported by Scientific Research Foundation for Returned Scholars of Heilongiiang Province (LC2016015), Young Talents Project of Northeast Agricultural University (14QC35), Specialized Fund Project for Harbin Innovative Talent in Science and Technology Research (2013RFQXJ094) and Starting Foundation for Ph.D. of Northeast Agricultural University (2012RCB72).

Author Contributions: W.J.G. conceived and designed the experiments; W.J.G., L.L. and X.L. performed the experiments; W.J.G. and H.L. analyzed the data; W.L. contributed reagents/materials/analysis tools; W.J.G., H.H.N. and W.G. contributed to the writing and revision of the article.

Conflicts of Interest: The authors declare no conflict of interest.

\section{References}

1. Bacenetti, J.; Negri, M.; Fiala, M.; González-García, S. Anaerobic digestion of different feedstocks: Impact on energetic and environmental balances of biogas process. Sci. Total Environ. 2013, 463, 541-551. [CrossRef] [PubMed]

2. Yilmaz, S.; Selim, H. A review on the methods for biomass to energy conversion systems design. Renew. Sustain. Energy Rev. 2013, 25, 420-430. [CrossRef]

3. Batstone, D.J.; Virdis, B. The role of anaerobic digestion in the emerging energy economy. Curr. Opin. Biotechnol. 2014, 27, 142-149. [CrossRef] [PubMed]

4. Weiland, P. Biogas production: Current state and perspectives. Appl. Microbiol. Biotechnol. 2010, 85, 849-860. [CrossRef] [PubMed]

5. Massé, D.; Masse, L.; Xia, Y.; Gilbert, Y. Potential of low-temperature anaerobic digestion to address current environmental concerns on swine production. J. Anim. Sci. 2010, 88, E112-E120. [CrossRef] [PubMed]

6. Nasir, I.M.; Mohd Ghazi, T.I.; Omar, R. Anaerobic digestion technology in livestock manure treatment for biogas production: A review. Eng. Life Sci. 2012, 12, 258-269. [CrossRef]

7. Rajagopal, R.; Massé, D.I.; Singh, G. A critical review on inhibition of anaerobic digestion process by excess ammonia. Bioresour. Technol. 2013, 143, 632-641. [CrossRef] [PubMed]

8. Appels, L.; Lauwers, J.; Degrève, J.; Helsen, L.; Lievens, B.; Willems, K.; Van Impe, J.; Dewil, R. Anaerobic digestion in global bio-energy production: Potential and research challenges. Renew. Sustain. Energy Rev. 2011, 15, 4295-4301. [CrossRef]

9. Buffiere, P.; Delgadillo Mirquez, L.; Steyer, J.P.; Bernet, N.; Delgenes, J.P. Anaerobic digestion of solid wastes needs research to face an increasing industrial success. Int. J. Chem. React. Eng. 2008, 6. [CrossRef]

10. Clements, L.; Salter, A.; Banks, C.; Poppy, G. The usability of digestate in organic farming. Water Sci. Technol. 2012, 66, 1864-1870. [CrossRef] [PubMed]

11. Bonetta, S.; Bonetta, S.; Ferretti, E.; Fezia, G.; Gilli, G.; Carraro, E. Agricultural reuse of the digestate from anaerobic co-digestion of organic waste: Microbiological contamination, metal hazards and fertilizing performance. Water Air Soil Pollut. 2014, 225, 2046. [CrossRef]

12. Nkoa, R. Agricultural benefits and environmental risks of soil fertilization with anaerobic digestates: A review. Agron. Sustain. Dev. 2014, 34, 473-492. [CrossRef]

13. Golkowska, K.; Vázquez-Rowe, I.; Lebuf, V.; Accoe, F.; Koster, D. Assessing the treatment costs and the fertilizing value of the output products in digestate treatment systems. Water Sci. Technol. 2014, 69, 656-662. [CrossRef] [PubMed]

14. Rehl, T.; Müller, J. Life cycle assessment of biogas digestate processing technologies. Resour. Conserv. Recycl. 2011, 56, 92-104. [CrossRef]

15. Fuchs, W.; Drosg, B. Assessment of the state of the art of technologies for the processing of digestate residue from anaerobic digesters. Water Sci. Technol. 2013, 67, 1984-1993. [CrossRef] [PubMed]

16. Gong, W.; Li, W.; Liang, H. Application of A/O-MBR for treatment of digestate from anaerobic digestion of cow manure. J. Chem. Technol. Biotechnol. 2010, 85, 1334-1339. [CrossRef]

17. Wellinger, A.; Murphy, J.D.; Baxter, D. The Biogas Handbook: Science, Production and Applications; Elsevier: Amsterdam, The Netherlands, 2013.

18. Gong, H.; Yan, Z.; Liang, K.; Jin, Z.; Wang, K. Concentrating process of liquid digestate by disk tube-reverse osmosis system. Desalination 2013, 326, 30-36. [CrossRef] 
19. Holloway, R.W.; Childress, A.E.; Dennett, K.E.; Cath, T.Y. Forward osmosis for concentration of anaerobic digester centrate. Water Res. 2007, 41, 4005-4014. [CrossRef] [PubMed]

20. Carney, K.; Rodgers, M.; Lawlor, P.; Zhan, X. Treatment of separated piggery anaerobic digestate liquid using woodchip biofilters. Environ. Technol. 2013, 34, 663-670. [CrossRef] [PubMed]

21. Comino, E.; Riggio, V.A.; Rosso, M. Constructed wetland treatment of agricultural effluent from an anaerobic digester. Ecol. Eng. 2013, 54, 165-172. [CrossRef]

22. Magrí, A.; Béline, F.; Dabert, P. Feasibility and interest of the anammox process as treatment alternative for anaerobic digester supernatants in manure processing-An overview. J. Environ. Manag. 2013, 131, 170-184. [CrossRef] [PubMed]

23. Libhaber, M.; Jaramillo, A.O. Sustainable Treatment and Reuse of Municipal Wastewater; Iwa Publishing: London, UK, 2012.

24. Li, Y.; Tang, F.; Zhao, Q.; Hu, K. Domestic wastewater treatment with cept-wetlands process. Int. J. Environ. Pollut. 2011, 45, 186-196. [CrossRef]

25. Pelendridou, K.; Michailides, M.K.; Zagklis, D.P.; Tekerlekopoulou, A.G.; Paraskeva, C.A.; Vayenas, D.V. Treatment of olive mill wastewater using a coagulation-flocculation process either as a single step or as post-treatment after aerobic biological treatment. J. Chem. Technol. Biotechnol. 2014, 89, 1866-1874. [CrossRef]

26. Wang, H.; Li, F.; Keller, A.A.; Xu, R. Chemically enhanced primary treatment (CEPT) for removal of carbon and nutrients from municipal wastewater treatment plants: A case study of shanghai. Water Sci. Technol. 2009, 60, 1803-1809. [CrossRef] [PubMed]

27. Xu, G.; Yan, Z.; Wang, Y.; Wang, N. Recycle of alum recovered from water treatment sludge in chemically enhanced primary treatment. J. Hazard. Mater. 2009, 161, 663-669. [CrossRef] [PubMed]

28. Driscoll, C.T.; Letterman, R.D. Factors regulating residual aluminium concentrations in treated waters. Environmetrics 1995, 6, 287-305. [CrossRef]

29. Sieliechi, J.M.; Kayem, G.J.; Sandu, I. Effect of water treatment residuals (aluminum and iron ions) on human health and drinking water distribution systems. Int. J. Conserv. Sci. 2010, 1, 175-182.

30. Association, A.P.H.; Association, A.W.W.; Federation, W.P.C.; Federation, W.E. Standard Methods for the Examination of Water and Wastewater: Including Bottom Sediments and Sludges; American Public Health Association: Washington, DC, USA, 1971; Volume 13.

31. Aguilar, M.; Saez, J.; Lloréns, M.; Soler, A.; Ortuno, J.; Meseguer, V.; Fuentes, A. Improvement of coagulation-flocculation process using anionic polyacrylamide as coagulant aid. Chemosphere 2005, 58, 47-56. [CrossRef] [PubMed]

32. Haydar, S.; Aziz, J.A. Coagulation-flocculation studies of tannery wastewater using combination of alum with cationic and anionic polymers. J. Hazard. Mater. 2009, 168, 1035-1040. [CrossRef] [PubMed]

33. Wong, S.; Teng, T.; Ahmad, A.; Zuhairi, A.; Najafpour, G. Treatment of pulp and paper mill wastewater by polyacrylamide (PAM) in polymer induced flocculation. J. Hazard. Mater. 2006, 135, 378-388. [CrossRef] [PubMed]

34. Mahmoud, E. Chemically enhanced primary treatment of textile industrial effluents. Pol. J. Environ. Stud. 2009, 18, 651-655.

(c) 2017 by the authors. Licensee MDPI, Basel, Switzerland. This article is an open access article distributed under the terms and conditions of the Creative Commons Attribution (CC BY) license (http://creativecommons.org/licenses/by/4.0/). 